\title{
PENGARUH RASIO KEUANGAN DAN MAKRO EKONOMI TERHADAP HARGA SAHAM PERUSAHAAN SEKTOR CONSUMER GOODS DI BEI
}

\author{
Dhira Maulana \\ Universitas negeri Surabaya \\ dhiramaulana@gmail.com
}

\begin{abstract}
This research examines the relation of financial ratio and macroeconomics to stock price. The financial ratios used in this research are the return on assets (ROA), debt to assets ratio (DAR), debt to equity ratio (DER), dan price earning ratio (PER). However, the macroeconomy uses inflation, Bank Indonesia rate, and exchange rate. The research sample uses secondary data such as annual reporting from consumer goods companies listed in Indonesia Stock Exchange (IDX). Twenty-eight companies were used as a sample in this research, using the purposive sampling technique. This research uses multiple regression analysis and uses SPSS 24.0 as a tool. This research shows that ROA, PER, and inflation had no significant influence on the stock price. On the other hand, DAR, DER, Bank Indonesia rate, and exchange rate significantly influenced the stock price. ROA does not have a significant influence on stock price can be caused by investors' view that ROA can be changed not only driven by corporate profits but can also be caused by the changes of corporate assets. So the decline in ROA does not always reflect a decrease in corporate profits but can be caused by an increase in corporate investments. PER does not have a significant influence on stock price can be caused by the high level of investor confidence in the prospects of consumer goods sector companies because the consumer goods sector contains companies that produce consumption needs. While inflation does not have a significant influence on stock price can be caused by the view of investors that inflation in the long term will not endanger the funds of investors who are in the capital market.
\end{abstract}

Keywords: leverage ratio; macro economic; market value ratio; profitability ratio; stock price.

\section{PENDAHULUAN}

Harga saham dapat diartikan sebagai harga yang terbentuk di pasar bursa pada waktu tertentu yang ditentukan dari permintaan dan penawaran saham yang bersangkutan oleh para pelaku pasar. Secara umum harga saham diperoleh untuk menghitung atau menentukan nilai dari suatu saham. Harga saham juga dapat dijadikan sebagai indikator keadaan suatu perusahaan (Jogiyanto, 2010).

Investor dituntut untuk selalu jeli dalam memilih saham yang akan dibeli. Maka dari itu, seorang investor perlu melakukan perhitungan dan pertimbangan yang matang dalam memilih saham. Dalam hal tersebut diperlukan informasi untuk mengetahui apa saja dan seberapa besar faktor-faktor tersebut dapat memengaruhi harga saham suatu perusahaan yang akan dibeli. Harga saham dapat dipengaruhi oleh faktor-faktor yang berasal dari dalam perusahaan maupun dari luar perusahaan (Patar et al., 2014).

Munawir (2004) menyatakan bahwa solvabilitas dapat dipakai untuk memperlihatkan kemampuan suatu perusahaan dalam memenuhi kewajiban mereka pada saat perusahaan tersebut dilikuidasi, baik kewajiban dalam jangka pendek ataupun jangka panjang. Untuk mengukur solvabilitas perusahaan dapat menggunakan rasio DAR (Debt to Asset Ratio) dan rasio DER (Debt to Equity Ratio) atau yang biasa disebut juga dengan Debt Ratio atau rasio hutang.

Menurut Hanafi (2004), rasio pasar dapat dipakai untuk menilai harga pasar saham suatu perusahaan, relatif terhadap nilai bukunya. PER merupakan salah satu rasio yang termasuk dalam rasio pasar. PER dapat menunjukkan seberapa besar para investor mau untuk membayarkan dari setiap rupiah pada laba yang telah dilaporkan (Moeljadi, 2006:75). Selain faktor internal, faktor eksternal juga memengaruhi harga saham perusahaan, misalnya inflasi, suku bunga, dan kurs valuta asing (Amarasinghe, 2015; Kewal, 2012). 
Dhira Maulana, Pengaruh Rasio Keuangan dan Makro Ekonomi terhadap Harga Saham pada Perusahaan Sektor Consumer Goods di BEI.

Menurut Fahmi (2015:61), inflasi adalah suatu peristiwa yang menggambaran situasi dan kondisi di mana nilai mata uang mengalami pelemahan sedangkan harga barang mengalami kenaikan. Apabila berlangsung terus menerus, kondisi tersebut dapat berdampak pada menurunnya kondisi ekonomi yang mana pasar modal termasuk di dalamnya.

Samuelson \& Nordhaus (2004:190) menyatakan bahwa suku bunga merupakan total bunga yang dibayarkan per unit waktu yang disebut sebagai persentase dari jumlah yang di pinjamkan. Amarasinghe (2015) dalam penelitiannya mendapatkan hasil bahwa tingkat suku bunga BI dapat memberikan pengaruh yang negatif secara signifikan pada harga saham.

Peran kurs atau nilai tukar sebagai indikator dari makro ekonomi juga dipercaya dapat memengaruhi harga saham. Nilai tukar adalah variabel makro ekonomi yang juga dapat memberikan dampak pada harga saham (Kewal, 2012). Nilai tukar rupiah terhadap dollar AS cenderung fluktuatif meningkat (Fauzian, 2017).

Perbedaan hasil penelitian terdahulu (reaserch gap) dan fenomena yang terjadi mendorong untuk melakukan penelitian yang bertujuan mendapatkan bukti empiris mengenai pengaruh rasio keuangan dan makro ekonomi terhadap harga saham pada perusahaan sektor consumer goods di Bursa Efek Indonesia. Tujuan penelitian ini untuk menganalisis pengaruh ROA, DAR, DER, PER, Inflasi, Suku Bunga BI, dan Kurs terhadap harga saham pada perusahaan sektor consumer goods yang terdaftar di BEI.

\section{KAJIAN PUSTAKA DAN PENGEMBANGAN HIPOTESIS}

\section{Signaling Theory}

Menurut Fahmi (2015), signaling theory merupakan teori yang membahas mengenai naik turunnya harga saham di pasar, sehingga akan dapat memberikan pengaruh terhadap keputusan yang diambil oleh investor. Sinyal yang diberikan berupa informasi tentang kinerja manajemen dalam memenuhi keinginan pemilik. Signaling theory menjelaskan dorongan perusahaan untuk memberikan informasi laporan keuangan pada pihak eksternal dikarenakan terdapat asimetri informasi antara pihak luar dengan perusahaan. Hal tersebut disebabkan karena perusahaan mengetahui lebih banyak tentang perusahaan dan prospek yang akan datang daripada pihak luar.

\section{Pecking Order Theory}

Sudana (2011:153) menyatakan bahwa pecking order theory didasarkan atas kesulitan untuk mendapatkan pendanaan dengan biaya yang rasional. Dalam teori ini, dijelaskan bahwa perusahaan cenderung lebih menyukai modal sendiri yang berasal dari dalam perusahaan dari pada modal yang berasal dari luar perusahaan dan akan memilih penggunaan sumber-sumber pendanaan yang memiliki resiko terendah terlebih dahulu. Urutan atau hierarki pendanaan dalam teori ini adalah laba ditahan, hutang dan yang terakhir barulah penerbitan saham.

\section{Efficient Market Hypothesis}

Pasar yang efisien merupakan suatu pasar bursa di mana dalam persaingan memeroleh keuntungan, semua informasi pengetahuan dan perkiraan direfleksikan secara akurat di dalam harga-harga pasar (Fahmi, 2015:268). Konsep pasar yang efisien ini menyatakan bahwa investor selalu memasukkan faktor informasi yang tersedia dalam keputusan mereka sehingga terefleksi pada harga yang mereka transaksikan (Jogiyanto, 2010:518).

\section{Harga Saham}

Saham atau sekuritas merupakan secarik kertas yang menunjukkan hak pemilik kertas tersebut untuk memeroleh bagian dari prospek atau kekayaan perusahaan yang menerbitkan sekuritas tersebut dan berbagai kondisi untuk melaksanakan hak tersebut (Husnan \& Pudjiastuti, 2006). Menurut Hopman (2007), fluktuasi harga saham akan memengaruhi penawaran dan permintaan di pasar. Dalam menentukan harga saham, pemodal disarankan untuk melakukan analisis terhadap saham dengan tujuan untuk mengetahui apakah harga saham yang ditawarkan oleh perusahaan wajar atau tidak. 


\section{Rasio Profitabilitas}

Rasio profitabilitas merupakan rasio untuk menilai kemampuan perusahaan dalam mencari keuntungan (Kasmir, 2015:196). Profitabilitas juga memberikan ukuran tingkat efektivitas manajemen suatu perusahaan, yang mana ditunjukkan oleh laba yang dihasilkan dari penjualan dan pendapatan investasi perusahaan tersebut (Kasmir, 2015:196). Dalam penelitian ini, rasio profitabilitas yang digunakan yaitu ROA (Return on Asset). ROA merupakan perbandingan laba bersih terhadap total aset yang mengukur pengembalian atas total aset perusahaan yang dirumuskan pada persamaan (1) (Brigham dan Houston, 2010:148).

Return on Asset $=\frac{\text { Laba Bersih }}{\text { Total Aset }}$

\section{Rasio Leverage atau Solvabilitas}

Kasmir (2015:150) menyatakan bahwa rasio leverage atau solvabilitas merupakan rasio yang digunakan untuk mengukur seberapa besar aktiva yang dimiliki oleh perusahaan dibiayai dengan hutang dan digunakan sebagai pengukur kemampuan perusahaan dalam membayar semua kewajiban yang dimiliki oleh perusahaan baik kewajiban jangka panjang maupun kewajiban jangka pendek". Terdapat beberapa rasio yang dapat digunakan untuk menghitung leverage dalam suatu perusahan diantaranya yaitu Debt to Asset Ratio (DAR) dan Debt to Equity Ratio (DER). DAR merupakan perbandingan antara total utang yang terdiri dari utang jangka pendek dan utang jangka panjang dengan seluruh aktiva yang dimiliki oleh perusahaan. DER merupakan rasio yang digunakan untuk menilai utang dengan ekuitas dengan cara membandingkan antara seluruh hutang, termasuk hutang lancar dengan seluruh ekuitas. Rumusan untuk mencari DAR dan DER dapat dilihat di persamaan (2) dan (3) (Kasmir, 2015).

$$
\begin{aligned}
& \text { Debt to Asset Ratio }=\frac{\text { Total Hutang }}{\text { Total Aset }} . . \\
& \text { Debt to Equity Ratio }=\frac{\text { Total Hutang }}{\text { Modal }} .
\end{aligned}
$$

\section{Rasio Nilai Pasar}

Rasio nilai pasar merupakan rasio yang terkait dengan penilaian kinerja saham perusahaan yang telah diperdagangkan di pasar modal (go public) (Sudana, 2011:23). Pada penelitian ini rasio nilai pasar yang digunakan adalah Price Earning Ratio (PER). Sudana (2011:23) menyatakan Price Earning Ratio merupakan cerminan harga saham yang bersedia dibayarkan oleh investor untuk setiap rupiah laba yang diperoleh perusahaan. Rumusan untuk menentukan PER dapat dilihat di persamaan (4).

Price Earning Ratio $=\frac{\text { Harga Saham }}{\text { Earning Per Share }}$.

\section{Inflasi}

Inflasi merupakan kenaikan harga yang akan berdampak terhadap penurunan daya beli uang (Islam, 2013). Fahmi (2015:61) menyatakan bahwa inflasi merupakan situasi dan kondisi di mana harga barang akan mengalami kenaikan dan nilai mata uang akan mengalami pelemahan. Peningkatan harga yang semakin tinggi akan memengaruhi turunnya nilai uang. Perhitungan tingkat inflasi dapat menggunakan rumus (5).

Inflasi $=\frac{I H K_{t}-I H K_{t-1}}{I H K_{t-1}}$ 
Dhira Maulana, Pengaruh Rasio Keuangan dan Makro Ekonomi terhadap Harga Saham pada Perusahaan Sektor Consumer Goods di BEI.

\section{Suku Bunga}

Samuelson dan Nordhaus (2004:190) menjelaskan bahwa suku bunga merupakan jumlah bunga yang dibayarkan per unit waktu. Suku bunga yang mengalami kenaikan tidak wajar akan menyulitkan dunia usaha untuk membayar beban bunga dan kewajiban. Hal ini dikarenakan suku bunga yang tinggi akan menambah beban bagi perusahaan sehingga secara langsung akan mengurangi profit perusahaan. Dalam penelitian ini menggunakan satuan ukur besarnya BI rate yang berlaku pada tanggal 31 Desember pada tiap tahun periode penelitian.

\section{Nilai Tukar}

Menurut Fahmi (2015:302), nilai tukar dapat diartikan sebagai nilai mata uang suatu negara yang dibandingkan dengan nilai mata uang dari negara lain. Jadi, nilai tukar rupiah merupakan nilai mata uang rupiah yang ditranslasikan ke dalam mata uang negara lain. Variabel makro ekonomi termasuk sebagai faktor yang dapat memengaruhi harga saham. Perubahan satu variabel makro ekonomi dapat memberikan dampak yang berbeda terhadap harga saham. Dampak yang dihasilkan tentu beragam, ada yang menghasilkan dampak positif ada juga yang memberikan dampak negatif. Dalam penelitian ini, nilai tukar yang digunakan adalah nilai tukar rupiah terhadap dolar Amerika yang diambil pada tanggal 31 Desember pada tiap tahun periode penelitian.

\section{Pengaruh antar Variabel}

Hasil penelitian yang dilakukan oleh Zuliarni (2012) menyebutkan bahwa ROA berpengaruh positif terhadap harga saham secara signifikan. Hal tersebut mengindikasikan bahwa semakin tinggi ROA, maka semakin baik dan semakin efektif suatu dalam memanfaatkan asset untuk menghasilkan laba bersih setelah pajak. Dengan begitu, daya tarik perusahaan kepada investor akan meningkat. Namun, ini berbeda dengan hasil penelitian yang didapatkan oleh Safitri (2013) yang mendapatkan hasil bahwa ROA tidak memiliki pengaruh yang signifikan terhadap harga saham. Hal tersebut menunjukkan bahwa dalam berinvestasi investor tidak perlu untuk memerhatikan ROA sebagai salah satu pertimbangan dalam mengambil keputusan investasinya.

\section{H1: ROA berpengaruh harga saham.}

Hasil penelitian yang dilakukan oleh Viandita, et al (2013) menemukan bahwa DAR memiliki pengaruh negatif yang signifikan terhadap harga saham. Penelitian tersebut menunjukkan bahwa dengan meningkatnya nilai DAR perusahaan akan dapat membuat harga saham menurun. Ini berbeda dengan hasil penelitian yang dilakukan oleh Widyatmini dan Damanik (2012) yang menemukan tidak ada pengaruh signifikan antara DAR dengan harga saham perusahaan.

H2: DAR berpengaruh terhadap harga saham.

Hasil penelitian yang dilakukan oleh Susilawati (2012) menemukan adanya pengaruh negatif DER terhadap harga saham yang signifikan. Yang mana hal tersebut menandakan bahwa semakin tinggi nilai DER suatu perusahaan, maka akan membuat harga saham perusahaan tersebut semakin melemah. Dalam penelitian lainnya, Safitri (2013) menemukan hasil yang berbeda pula, di mana tidak didapatkan pengaruh yang signifikan antara DER dengan harga saham.

\section{H3: DER berpengaruh terhadap harga saham.}

Penelitian yang dilakukan oleh Safitri (2013) mendapatkan hasil bahwa PER memiliki pengaruh positif yang signifikan terhadap harga saham. Namun, hasil berbeda didapatkan oleh Widyatmini \& Damanik (2012) di mana dalam penelitiannya mendapatkan hasil bahwa PER tidak memiliki pengaruh yang signifikan terhadap harga saham.

H4: PER berpengaruh terhadap harga saham.

Penelitian Yogaswari et al (2012) menunjukkan adanya pengaruh negatif signifikan terhadap harga saham. Hal tersebut dikarenakan biaya produksi yang tinggi akan membuat tingkat profitabilitas 
perusahaan turun sehingga akan mengakibatkan investor enggan menanamkan dananya di perusahaan tersebut yang akan berdampak terhadap penurunan harga saham.

H5: Inflasi berpengaruh terhadap harga saham.

Oktarina (2016) melakukan penelitian terhadap perusahaan yang termasuk dalam Jakarta Islamic Index di BEI menyatakan hasil penelitiannya dengan lebih jelas bahwa tingkat bunga BI memiliki pengaruh negatif terhadap harga saham. Namun penelitian yang dilakukan oleh Beik \& Fatmawati (2014) menunjukkan hasil yang berbeda di mana pada penelitian tersebut tingkat suku bunga BI tidak memiliki pengaruh yang signifikan terhadap harga saham.

H6: Suku bunga Bank Indonesia berpengaruh terhadap harga saham.

Penelitian yang dilakukan oleh Kewal (2012) membuktikan pernyataan tersebut bahwa nilai tukar rupiah berpengaruh negatif terhadap harga saham. Hal tersebut menunjukkan bahwa dengan menguatnya nilai tukar rupiah akan membuat harga saham perusahaan meningkat. Namun hasil yang berbeda ditemukan dalam penelitian yang dilakukan oleh Zhao (2009) yang menunjukkan bahwa nilai tukar rupiah tidak memiliki pengaruh yang signifikan terhadap harga saham.

H7: Nilai Tukar berpengaruh terhadap harga saham.

\section{METODE PENELITIAN}

Penelitian ini menggunakan jenis penelitian kausalitas. Sumber data yang digunakan dalam penelitian ini adalah sumber sekunder dan dengan menggunakan metode dokumentasi, yaitu alat pencarian melalui catatan-catatan serta dokumen tertulis yang berhubungan dengan variabel yang digunakan dalam penelitian ini. Populasi dalam penelitian ini adalah seluruh perusahaan yang termasuk dalam sektor consumer goods yang tercatat pada Bursa Efek Indonesia (BEI) dari tahun 2009-2016. Penarikan sampel dalam penelitian ini dilakukan dengan menggunakan metode purposive sampling. Adapun pertimbangan yang digunakan adalah perusahaan sektor consumer goods yang tidak delisting pada periode penelitian dan tersedia data laporan keuangan yang lengkap. Pada penelitian ini teknik pengumpulan data yang digunakan yaitu metode dokumentasi. Metode dokumentasi dilakukan dengan cara mengumpulkan data sekunder dari situs www.sahamok.com, situs Badan Pusat Statistik www.bps.go.id, situs Bank Indonesia www.bi.go.id, dan situs Bursa Efek Indonesia (BEI) www.idx.co.id. Variabel dependen dalam penelitian ini adalah harga saham. Harga saham yang digunakan adalah closing price di BEI per tanggal 30 Desember tiap tahunnya. Variabel independen yang digunakan adalah ROA, DAR, DER, PER, inflasi, suku bunga BI, dan nilai tukar. Data penelitian dianalisis dengan Regresi Linear Berganda dengan software SPSS.

\section{HASIL DAN PEMBAHASAN}

\section{Hasil Uji Asumsi Klasik}

Uji asumsi klasik dalam penelitian ini adalah uji normalitas, uji autokorelasi, uji multikolinieritas, dan uji heteroskedastisitas. Dalam penelitian ini, uji normalitas menggunakan uji statistik non-parametrik Kolmogrov-Smirnov (K-S) di mana nilai asymp. sig. (2-tailed) yang diperoleh dari uji statistik nonparametrik K-S adalah sebesar 0,081, di mana nilai tersebut lebih besar dari 0,05 sehingga data tersebut telah berdistribusi normal.

Uji Autokorelasi dalam penelitian ini menggunakan uji Durbin-Watson (Durbin-Watson Test). Hasil pengujian menunjukkan pada tingkat kesalahan 0,05 dan jumlah sampel 224 diperoleh nilai Durbin Watson dari model regresi adalah 2,072. Berdasarkan nilai Durbin-Watson (dW) dan nilai dU yang diperoleh dari tabel Durbin-Watson pada tingkat signifikasi 5\%, maka data penelitian tidak mengalami gejala autokorelasi. 
Dhira Maulana, Pengaruh Rasio Keuangan dan Makro Ekonomi terhadap Harga Saham pada Perusahaan Sektor Consumer Goods di BEI.

Uji Multikolinieritas pada penelitian ini menggunakan nilai tolerance dan VIF. Hasil masing-masing variabel bebas memiliki nilai tolerance lebih dari 0, 10 dan nilai VIF kurang dari 10. Maka data penelitian terbebas dari multikoliniearitas.

Uji heteroskedastistas dilakukan dengan menggunakan uji Glejser. Uji Glejser dalam penelitian ini menunjukkan bahwa Signifikan hitung (Sig) untuk seluruh variabel $>0,05$, sehingga pada penelitian ini tidak mengalami gejala heteroskedastisitas.

\section{Hasil Analisis Regresi Linier Berganda}

Berdasarkan hasil yang terdapat pada Tabel 1, dapat disusun persamaan regresi linier berganda (6).

Price $=-258,867+1354,084 \mathrm{DAR}+1218,776 \mathrm{DER}-45220,626 \mathrm{BI}+0,252 \mathrm{NT}+e$

Tabel 1.

HASIL ANALISIS REGRESI LINIER BERGANDA

\begin{tabular}{lcc}
\hline \multicolumn{1}{c}{ Model } & B & Sig. \\
\hline (Const) & $-258,867$ &, 793 \\
ROA & $-158,988$ &, 723 \\
DAR & 1354,084 &, 000 \\
DER & 1218,776 &, 000 \\
PER & $-4,118$ &, 362 \\
INFL & 4287,129 &, 564 \\
BI & $-45220,626$ &, 050 \\
NT &, 252 &, 010 \\
\hline \multicolumn{3}{l}{ Sumber: Data diolah (2017) }
\end{tabular}

Berdasarkan hasil uji t, ROA menunjukkan nilai signifikansi sebesar 0,723 , di mana nilai tersebut lebih besar dari 0,05 , sedangkan untuk nilai $t$ diperoleh nilai $t_{\text {hitung }}-0,356$ lebih besar dari $-t_{\text {tabel }}$ yaitu 1,6566, sehingga bahwa ROA tidak berpengaruh terhadap harga saham. Hal tersebut menunjukkan bahwa penelitian ini gagal membukitikan H1.

DAR menunjukkan nilai signifikansi sebesar 0000 yang lebih kecil dari 0,05 dan untuk nilai $t_{\text {hitung }}$ diperoleh nilai sebesar 12,747 yang mana nilai tersebut lebih besar dari nilai $t_{\text {tabel }}$ yang diperoleh yaitu 1,6566, sehingga DAR berpengaruh terhadap harga saham. Hal tersebut membuktikan H2.

DER menunjukkan nilai $t_{\text {hitung }}$ sebesar 19,359 yang lebih besar dari nilai $t_{\text {tabel }} 1,6566$. Sedangkan untuk nilai signifikansi sebesar 0,000, di mana nilai tersebut lebih kecil dari 0,05 sehingga DER berpengaruh terhadap harga saham. Hal tersebut membuktikan $\mathrm{H} 3$.

PER menunjukkan nilai $t_{\text {hitung }}$ sebesar $-0,915$ lebih besar dari nilai $-t_{\text {tabel }}(-1,6566)$, sedangkan signifikansi sebesar 0,362, di mana nilai tersebut lebih besar dari 0,05. PER tidak berpengaruh terhadap harga saham. Dengan kata lain, hasil penelitian ini tidak mampu membuktikan H4.

Inflasi menunjukkan nilai signifikansi sebesar 0,564, di mana nilai tersebut lebih besar dari 0,05. Sedangkan nilai $t_{\text {hitung }}$ diperoleh nilai sebesar 0,579 , di mana nilai tersebut lebih kecil dari nilai $t_{\text {tabel }}$ yaitu 1,6566, sehingga inflasi tidak berpengaruh terhadap harga saham. H5 tidak terbukti.

Suku Bunga BI menunjukkan nilai signifikansi sebesar 0,050, di mana nilai tersebut sama dengan 0,05 dan untuk nilai $t_{\text {hitnung }}$ yang diperoleh adalah sebesar $-1,981$ lebih kecil dari nilai $-t_{\text {tabel }}$ yang memiliki nilai $-1,6566$, sehingga dapat suku bunga BI berpengaruh terhadap harga saham. H6 terbukti.

Nilai Tukar Rupiah terhadap Dolar Amerika menunjukkan nilai thitung sebesar 2,609, di mana nilai tesebut lebih besar dari nilai $t_{\text {tabel }}$ sebesar 1,6566. Sedangkan untuk signifikansi diperoleh nilai sebesar 
0,010, di mana nilai tersebut lebih kecil dari 0,05. Hal tersebut berarti bahwa Nilai Tukar Rupiah terhadap Dolar Amerika berpengaruh terhadap harga saham. H7 dapat dibuktikan.

Uji koefisien determinasi diukur dari nilai Adjusted $R$ Square yang didapatkan dari hasil regresi linier berganda. Hasil uji koefisien determinasi dapat dilihat pada tabel 2:

Tabel 2.

Hasil Uji Koefisien Determinasi

\begin{tabular}{cccc}
\hline Model & $\mathbf{R}$ & $\boldsymbol{R}$ Square & Adjusted $\boldsymbol{R}$ Square \\
\hline 1 &, 974 &, 948 &, 945 \\
\hline \multicolumn{2}{l}{ Sumber: Data diolah $(2017)$} &
\end{tabular}

Berdasarkan nilai yang tertera pada tabel 2, didapatkan nilai Adjusted $R$ Square sebesar 0,945 $(94,5 \%)$. Hal tersebut menunjukkan bahwa variabel bebas yang digunakan dalam dalam penelitian ini dapat memprediksi harga saham untuk perusahaan sektor consumer goods sebesar $94,5 \%$. Sedangkan sisanya $(5,5 \%)$ dipengaruhi oleh variabel lain di luar model penelitian.

\section{Pengaruh ROA terhadap Harga Saham}

Hasil yang didapatkan dalam penelitian ini menunjukkan bahwa Return on Assets (ROA) tidak memiliki pengaruh yang signifikan terhadap harga saham perusahaan pada sektor consumer goods di BEI. Hal tersebut dapat disebabkan oleh peningkatan ataupun penurunan nilai ROA suatu perusahaan tidak selama dipengaruhi oleh peningkatan ataupun penurunan keuntungan perusahaan tersebut semata. Namun juga dipengaruhi oleh peningkatan atau penurunan dari nilai total aset perusahaan tersebut juga, sehingga tidak selamanya penurunan nilai ROA suatu perusahaan merupakan sesuatu hal yang buruk, namun bisa jadi penurunan tersebut disebabkan oleh nilai aset perusahaan yang meningkat lebih tinggi daripada peningkatan keuntungan perusahaan di mana dapat digunakan untuk peningkatan kinerja perusahaan kedepannya dan justru dapat meningkatkan nilai perusahaan. Penelitian ini sejalan dengan penelitian yang dilakukan oleh Safitri (2013) yang tidak dapat membuktikan pengaruh ROA terhadap harga saham.

\section{Pengaruh DAR terhadap Harga Saham}

Hasil dalam penelitian ini diperoleh hasil bahwa Debt to Assets Ratio (DAR) memiliki pengaruh yang signifikan terhadap harga saham. Hasil tersebut sesuai dengan hipotesis yang telah ditentukan, di mana DAR dapat berpengaruh terhadap harga saham. Pengaruh yang dihasilkan oleh DAR terhadap harga saham adalah pengaruh positif, di mana hal tersebut menunjukkan bahwa perubahan nilai DAR suatu perusahaan akan berdampak sejalan dengan perubahan harga saham perusahaan tersebut. Hasil yang didapatkan dalam penelitian ini sama dengan Viandita, et al (2013).

\section{Pengaruh DER terhadap Harga Saham}

Hasil yang ditunjukkan dalam penelitian ini adalah DER mempunyai pengaruh positif yang signifikan terhadap harga saham. Hal tersebut mengungkapkan bahwa peningkatan nilai DER suatu perusahaan akan dapat meningkatkan harga saham perusahaan tersebut, dan begitu pula sebaliknya. Tinggi rendahnya nilai DER merupakan cerminan dari tinggi rendahnya nilai utang suatu perusahaan. Pengaruh positif yang signifikan antara DER terhadap harga saham disebabkan oleh pandangan rasional para investor yang melihat bahwa penggunaan utang yang tinggi dalam perusahaan akan dapat meningkatkan nilai perusahaan (Sudana, 2011). Hasil dalam penelitian ini mendukung Susilawati (2012).

\section{Pengaruh PER terhadap Harga Saham}

Hasil yang diperoleh dalam penelitian ini mengenai pengaruh PER terhadap harga saham adalah PER tidak memiliki pengaruh yang signifikan terhadap harga saham. Hasil tersebut menunjukkan bahwa para investor cenderung mengabaikan PER dalam proses pengambilan keputusan investasinya. PER tidak memiliki pengaruh yang signifikan terhadap harga saham disebabkan oleh kepercayaan yang tinggi oleh para investor terhadap perusahaan-perusahaan yang tercatat dalam sektor consumer goods, 
Dhira Maulana, Pengaruh Rasio Keuangan dan Makro Ekonomi terhadap Harga Saham pada Perusahaan Sektor Consumer Goods di BEI.

di mana sebagian besar perusahaan-perusahaan tersebut merupakan perusahaan yang memproduksi kebutuhan-kebutuhan konsumsi masyarakat Indonesia. Sehingga para investor pun akan tetap percaya mengenai prospek pertumbuhan perusahaan di masa depan tanpa memerhatikan besar ataupun kecilnya nilai PER yang dimiliki oleh perusahaan-perusahaan tersebut. Hasil penelitian ini sejalan dengan hasil penelitian yang didapatkan oleh Permana dan Sularto (2008) yang dalam penelitian tersebut juga mendapatkan hasil bahwa Price Earning Ratio (PER) tidak memiliki pengaruh yang signifikan terhadap harga saham perusahaan.

\section{Pengaruh Inflasi terhadap Harga Saham}

Penelitian ini memeroleh hasil bahwa inflasi tidak memiliki pengaruh yang signifikan terhadap harga saham. Hasil tersebut berbeda dengan hipotesis yang telah ditetapkan, dengan begitu inflasi akan cenderung diabaikan oleh para investor dalam pengambilan keputusan investasinya. Inflasi tidak berpengaruh signifikan terhadap harga saham perusahaan disebabkan oleh inflasi dalam jangka panjang tidak akan membahayakan dana para investor yang berada di pasar modal. Adanya intervensi pemerintah dalam mengatur laju inflasi tentunya akan dapat memberikan kepercayaan diri tersendiri kepada para investor untuk menanamkan dananya dalam pasar modal. Hasil dalam penelitian ini sejalan dengan hasil penelitian yang dilakukan oleh Permana dan Sularto (2008) yang menunjukkan bahwa inflasi tidak memiliki pengaruh yang signifikan terhadap harga saham.

\section{Pengaruh Suku Bunga Bank Indonesia terhadap Harga Saham}

Hasil dalam penelitian ini menunjukkan bahwa suku bunga Bank Indonesia memiliki pengaruh yang signifikan terhadap harga saham. Pengaruh yang dihasilkan oleh suku bunga Bank Indonesia adalah pengaruh negatif, di mana dengan meningkatnya nilai suku bunga Bank Indonesia maka akan dapat membuat penurunan pada harga saham perusahaan dan begitu pula sebaliknya. Hal ini disebabkan oleh tingkat suku bunga Bank Indonesia merupakan patokan dalam menentukan besarnya bunga kredit dan bunga tabungan, dengan begitu ketika tingkat suku bunga BI mengalami peningkatan maka hal tersebut dapat diikuti dengan peningkatan bunga tabungan. Penelitian ini memiliki hasil yang sama dengan penelitian yang pernah dilakukan sebelumnya oleh Oktarina (2016) dan Amarasinghe (2015). Kedua penelitian tersebut juga memeroleh hasil bahwa tingkat suku bunga memiliki pengaruh yang signifikan terhadap harga saham perusahaan.

\section{Pengaruh Nilai Tukar Rupiah pada Dolar Amerika terhadap Harga Saham}

Hasil yang diperoleh dalam penelitian ini menunjukkan bahwa nilai tukar Rupiah terhadap Dolar Amerika memiliki pengaruh yang signifikan terhadap harga saham. Pengaruh yang dihasilkan oleh nilai tukar Rupiah terhadap Dolar Amerika adalah pengaruh positif, di mana setiap peningkatan nilai tukar Rupiah terhadap Dolar Amerika akan dapat meningkatkan harga saham perusahaan dan begitu pula sebaliknya. Hal tersebut dapat disebabkan oleh dengan meningkatnya nilai tukar Rupiah terhadap Dolar Amerika (pelemahan nilai tukar Rupiah) dapat membuat para investor yang melakukan investasi langsung pada pasar uang untuk mengalihkan dana investasi mereka ke dalam investasi langsung pada pasar modal, dengan begitu dapat menyebabkan minat akan saham-saham perusahaan meningkat dan dapat berdampak pada peningkatan harga saham-saham perusahaan tersebut. Hasil penelitian yang diperoleh sejalan dengan hasil penelitian yang dilakukan oleh Amin (2012) dan Kewal (2012) yang juga mendapatkan hasil bahwa nilai tukar memiliki pengaruh terhadap harga saham.

\section{Implikasi Manajerial}

Penelitian ini bermanfaat sebagai bahan pertimbangan perusahaan dalam pengambilan keputusan pendanaan. Hutang yang dilakukan perusahaan memiliki dampak positif pada harga saham. Artinya perusahaan mampu mengelola hutang dengan baik sehingga menghasilkan keuntungan perusahaan. Penggunaan utang yang tinggi dalam perusahaan akan dapat meningkatkan nilai perusahaan yang tercermin dari harga saham. Bagi investor saham khususnya yang berinvestasi pada perusahaan sektor consumer goods untuk memerhatikan rasio leverage perusahaan yaitu DAR dan DER serta tingkat suku bunga, dan nilai tukar sebagai pertimbangan dalam pengambilan keputusan berinvestasi, mengingat faktor-faktor tersebut dapat memengaruhi harga saham perusahaan. Dengan pertimbangan dan analisis yang matang diharapkan bisa menghasilkan tingkat return yang optimal. 


\section{KESIMPULAN}

Berdasarkan hasil penelitian dan analisis yang dilakukan dengan menggunakan sampel perusahaanperusahaan sektor consumer goods yang terdaftar dalam Bursa Efek Indonesia, maka dapat diambil kesimpulan bahwa Return on Asset (ROA), Price Earning Ratio (PER) dan Inflasi terbukti tidak berpengaruh signifikan terhadap harga saham. Sedangkan Debt to Assets Ratio (DAR), Debt to Equity Ratio (DER), Suku Bunga BI, dan Nilai tukar Rupiah terhadap Dolar Amerika terbukti memiliki pengaruh yang signifikan terhadap harga saham.

Penelitian selanjutnya agar dapat memeroleh hasil secara umum dan luas, diharapkan agar objek penelitian tidak hanya terbatas pada perusahaan sektor consumer goods namun dapat menggunakan seluruh perusahaan yang terdaftar dalam Bursa Efek Indonesia. Selain itu, pada variabel harga saham dapat menggunakan nilai rata-rata bulanan atau mingguan agar dapat lebih memerlihatkan fluktuasi yang terjadi pada variabel harga saham di tahun tertentu.

\section{DAFTAR PUSTAKA}

Amarasinghe, AAMD. (2015). Dynamic Relationship between Interest Rate and Stock Price: Empirical Evidence from Colombo Stock Exchange. International Journal of Business and Social Science, 6. 4, 92-97.

Amin, Muhammad Zuhdi. (2012). Pengaruh Tingkat Inflasi, Suku Bunga SBI, Nilai Kurs Dollar (USD/IDR), dan Indeks Dow Jones (DJIA) terhadap Pergerakan Indeks Harga Saham Gabungan di Bursa Efek Indonesia (BEI) Periode 2008-2011. Jurnal Ilmiah FEB UB, 1(1). 117.

Aurora, Tona, dan Riyadi, Agus. (2013). Pengaruh Inflasi, Suku Bunga, dan urs Terhadap Indeks LQ45 di Bursa Efek Indonesia Periode Tahun 2007-2011. Jurnal Dinamika Manajemen, 1. (3). 183-197

Beik, Irfan Syauqi, dan Fatmawati, Sri Wulan. (2014). Pengaruh Indeks Harga Saham Syariah Internasional dan Variabel Makroekonomi terhadap Jakarta Islamic Index. Al-Iqtishad Jurnal Ilmu Ekonomi Syariah, 6. 2, 155-178.

Brigham, Eugene F., dan Houston, Joel F. (2010). Dasar-Dasar Manajemen Keuangan. Edisi Sebelas. Jakarta: Salemba Empat.

Fahmi, Irham. (2015). Manajemen Investasi. Edisi Kedua. Jakarta: Salemba Empat

Fauzian, Rizkie. (2017). Perjalanan Rupiah vs Dolar AS Sepanjang 2017, Terombang-ambing di Kisaran

Rp13.600/USD. https://economy.okezone.com/read/2017/12/12/278/1829334/perjalanan-rupiah-vs-dolar-assepanjang-2017-terombang-ambing-di-kisaran-rp13-600-usd, diakses pada 1 Juni 2021.

Hanafi, Mamduh. (2004). Manajemen Keuangan. Yogyakarta: BPFE UGM.

Herdiansyah, Haris. (2010). Metodologi Penelitian Kuantitatif. Jakarta: Salemba Humanika.

Hopman, C. (2007). Do supply and demand drive stock prices?. Quantitative Finance, 7(1), 37-53.

Husnan, Suad, dan Pudjiastuti, Enny. (2006). Dasar-Dasar Manajemen Keuangan. Edisi Kelima. Yogyakarta: UPP STIM YKPN.

Indonesia, Bank. (2017). BI Rate. Diakses Pada 15 Maret, 2017, dari http://www.bi.go.id/id/moneter/bi-rate/penjelasan/Contents/Default.aspx 
Dhira Maulana, Pengaruh Rasio Keuangan dan Makro Ekonomi terhadap Harga Saham pada Perusahaan Sektor Consumer Goods di BEI.

Islam, M. A. (2013). Impact of inflation on import: An empirical study. International Journal of Economics, Finance and Management Sciences, 1(6), 299-309.

Jogiyanto, H. M. (2010). Teori Portofolio dan Analisis Investasi. Edisi Ketujuh. Yogyakarta: BPFE.

Kasmir. (2015). Analisis Laporan Keuangan. Jakarta: PT. RajaGrafindo Persada.

Kewal, Suramaya Suci. (2012). Pengaruh Inflasi, Suku Bunga, Kurs, dan Pertumbuhan PDB Terhadap Indeks Harga Saham Gabungan. Jurnal Economia, Vol. 8. No. 1, 53-64.

Moeljadi. (2006). Manajemen Keuangan Pendekatan Kuantitatif dan Kualitatif. Edisi Pertama. Malang: Bayu Media Publishing.

Munawir, S. (2004). Analisis Laporan Keuangan. Edisi Keempat. Yogyakarta: Liberty.

Oktarina, Dian. (2016). Pengaruh Beberapa Indeks Saham Global dan Indikator Makroekonomi terhadap Pergerakan IHSG. Journal of Business \& Banking, 5. 2, 163-182.

Patar, Andrew., Darminto.,Saifi, Muhammad. (2014). Faktor Internal dan Eksternal yang Mempengaruhi Pergerakan Harga Saham (Studi Pada Saham-Saham Indeks LQ45 Periode 2009-2013). Jurnal Administrasi Bisnis, 11(1).1-9.

Permana, Yogi, dan Sularto, Lana. (2008). Analisis Pengaruh Fundamental Keuangan, Tingkat Bunga SBI dan Tingkat Inflasi Terhadap Pergerakan Harga Saham. Jurnal Ilmiah Ekonomi Bisnis Universitas Gunadarma, 13. (2).103-111.

Safitri, Abied Luthfi. (2013). Pengaruh Earning Per Share, Price Earning Ratio, Return On Asset, Debt To Equity Ratio dan Market Value Added Terhadap Harga Saham Dalam Kelompok Jakarta Islamic Index. Management Analysis Journal, 2 (2). 1-8.

Samuelson, Paul A., dan Nordhaus, William D. (2004). Ilmu Makro Ekonomi. Edisi Ke-17. Jakarta: PT. Media Global Edukasi.

Sudana, I Made. (2011). Manajemen Keuangan Perusahaan Teori \& Praktik. Jakarta: Erlangga.

Susilawati, Christine Dwi Karya. (2012). Analisis Perbandingan Pengaruh Likuiditas, Solvabilitas, dan Profitabilitas Terhadap Harga Saham pada Perusahaan LQ45. Jurnal Akuntansi, 4. 2, 165174.

Viandita, Tamara Oca, Suhadak, dan Husaini, Achmad. (2013). Pengaruh Debt Ratio (DR), Price to Earning Ratio (PER), Earning Per Share (EPS), dan Size Terhadap Harga Saham (Studi pada Perusahaan Industri yang Terdaftar di Bursa Efek Indonesia). Jurnal Administrasi Bisnis (JAB), Vol. 1. No. 2, 113-121.

Widyatmini, dan Damanik, Valentino. (2012). Pengaruh Economic Value Added (EVA) dan Analisis Fundamental Terhadap Harga Saham (Studi Pada Sektor Industri Perdagangan Retail). EJournal Ekonomi, Universitas Gunadarma.14(1).39-50.

Yogaswari, Dhira Dwijayanti, Nugroho, Anggoro Budi, dan Astuti, Novika Candra. (2012). The Effect of Macroeconomic Variables on Stock Price Volatility: Evidence from Jakarta Composite Index, Agriculture, and Basic Industry Sector. Journal of Business and Management, 46, 96-100.

Zhao, Hua. (2009). Dynamic Relationship Between Exchange Rate and Stock Price: Evidence from China. Research in International Business and Finance, 24. 2, 103-112. 
Zuliarni, Sri. (2012). Pengaruh Kinerja Keuangan terhadap Harga Saham pada Perusahaan Mining And Mining Service di Bursa Efek Indonesia (BEI). Jurnal Aplikasi Bisnis, 3. 1, 36-48. 